\title{
WRITING AND PUBLISHING A MAGAZINE
}

\author{
Susie Kusumayanthi \\ STKIP Pasundan, Indonesia \\ Email: susieasrul@gmail.com \\ Final Proof Received: March 2019
}

\begin{abstract}
Students who write a piece of writing need a perfect tool to engage themselves to write even when they are not interested in writing at all. One of the perfect tools to engage the students in writing process is creating a magazine as it offers students to publish their writing. Publication, according to Lange (1992) is a great tool to engage students to write, involving even those who do not consider themselves to be writers. This paper explores the implementation of writing and publishing a magazine in a writing class in one of the universities in Bandung. The class applies project-based learning as its teaching method.
\end{abstract}

Keywords: Writing, tools, magazine, publication, project-based learning

\section{INTRODUCTION}

Research has revealed that writing is often considered as a difficult skill to be mastered because of its complexity. Youn-Hee (2011) states that writing skill is a complicated skill because to construct writing, students need to constitute a variety of linguistic and nonlinguistic components such as phonemes, morphemes, lexemes, syntax, and context.

In line with this, Brown (2007) remarks that writing is undeniably a very complex process. He mentions that student will repeatedly have difficulty with spelling, punctuation, capitalization and learning basic grammar rules early on; he continues that as the demands placed on the student become more complex, different difficulties, such as: planning, organization, editing, and revising will often become perceivable. Furthermore, Brown (2007) remarks that when struggling with basic skills become magnified and more problematic as academic tasks become more challenging, students will often try to avoid it at all costs. However, there are several things that teacher can do to support their students; one of the things is by arranging activities that can help the students to be engaged in learning.

In learning a foreign language, students ${ }^{e e}$ high degree of engagement may improve their progress; moreover, it is believed that learning improves when students are inspired or interested. Educators need to stimulate and support learning by arranging activities that can help the students to be engaged in, inspired by, and interested in learning. There are several activities that can stimulate and support learning; one of which is creating a magazine as one of the ways to publish students ${ }^{\text {ee }}$ writing assignment as the final stage of their writing process.

Publication, according to Lange (1992) is a great tool for many students, involving even those who do not consider themselves to be writers. Research has demonstrated the importance of publication for students ${ }^{e e}$ writing. According to Sheedlo (1998), there is a rationale around five principal reasons for publication: (1) publication teaches and facilitates better adjustment to audience, (2) multiple writing skills learned in context, (3) improved and sustained motivation for writing, (4) development of a more effective learning community for writing, and (5) more critical and appreciative reading. The importance of publication is also shown recently by Schulten (2018), whose research is to find reasons for publishing students ${ }^{\text {ee }}$ writing. Schulten's research (2018) involved 
several teachers whose students write for some publications. She gathered data and found out that publishing students ${ }^{\text {ee }}$ writing acquires the students to: (1) get an "authentic audience", (2) become enthusiastic writers who want to revise, (3) take their work more seriously, (4) do something real with what they have learned, and (5) engage in reading. Thus, it can be concluded that publication gives significant advantages for students.

Departing from this, the current paper highlights the implementation of writing and publishing a magazine as one of the media to publish students ${ }^{\text {ee }}$ writing assignment as the final stage of their "writing process". The definition of magazine in this paper is a type of thin book with small pages (10-12 pages long) and a paper cover that contains articles (5-10 articles depending on the number of the students in one group) and photographs and is published only one time. The research is conducted in a writing class which applies project-based learning as its teaching method. The research includes: (a) how are writing and publishing a magazine designed and implemented? And (b) what are the students' opinions toward publishing their writing assignment as the final stage of their writing process?

This paper is not comprehensive and has many limitations, yet it is expected that this paper will, to some extent, give contribution to cultivate pedagogical knowledge in arranging activities that can help the students to be engaged in, inspired by, and interested in learning.

The literature review focuses on writing skill, writing process, and project-based learning in order to answer the research questions which include: (a) how are writing and publishing a magazine designed and implemented?, and (b) what are the students' opinions toward publishing their writing assignment as the final stage of their writing process?

\section{Writing Skill and Writing Process}

As mentioned on the background of this study, research by Brown (2007) and Youn-Hee (2011) have revealed that writing is often considered as a difficult skill to be mastered because of its complexity.

However, there are several things that teachers can do to support the learning of the writing skills that will help their students to have confidence that they, too, can be writing experts!

To support the students to be writing experts, some researchers such as Seow (2014) and Schulten (2018) remark that the teacher has to give awareness to the studentwriters that they are writing for a real audience. Students need to determine the register and tone of writing based on a target audience and the purpose of writing. Seow (2014) highlights that all experienced writers write with an implicit audience in mind; moreover, Schulten (2018) states that giving awareness for a real audience would make the students take their work more seriously.

To prepare student-writers writing for a real audience, the teacher needs to support the students by preparing stages of learning experience as well as applying appropriate teaching method.

One of the ways of preparing stages of learning experience is proposed by Seow (2014) who puts forward the writing process which include: planning, drafting, responding, revising, editing, evaluating, and post-writing. The writing process also covers the learning experience, understanding the learning process, and teaching process writing. The process is presented in Table 1, as follows: 
Table 1. The writing process (Seow, 2014)

\begin{tabular}{|c|c|c|}
\hline Learning Experience & Understanding the Writing Process & Teaching Process Writing \\
\hline 1. Planning (Pre-writing) & $\begin{array}{l}\text { Students are motivated to write because } \\
\text { they feel they have something } \\
\text { important to say }\end{array}$ & $\begin{array}{l}\text { Teacher engages students } \\
\text { in generating ideas, in } \\
\text { sourcing for information } \\
\text { (content) and in } \\
\text { collaborative discussions. }\end{array}$ \\
\hline 2. Drafting (Writing) & $\begin{array}{l}\text { Students organize their ideas and } \\
\text { develop some form to their writing. }\end{array}$ & $\begin{array}{l}\text { Teacher guides students in } \\
\text { the composing process. }\end{array}$ \\
\hline 3. $\quad$ Responding (Sharing) & $\begin{array}{l}\text { Students look to the teacher and peers } \\
\text { for support and feedback. }\end{array}$ & $\begin{array}{l}\text { Teacher and peers provide } \\
\text { initial reactions to } \\
\text { students }{ }^{\text {ee }} \text { first drafts. }\end{array}$ \\
\hline 4. Revising (Redrafting) & $\begin{array}{l}\text { Students capitalize on audience } \\
\text { feedback to re-examine their drafts for } \\
\text { clarity of intention and meaning and } \\
\text { make necessary changes. }\end{array}$ & $\begin{array}{l}\text { Teacher takes students } \\
\text { through the revision stage } \\
\text { to help students shape and } \\
\text { reshape their texts into a } \\
\text { viable (final) form. }\end{array}$ \\
\hline 5. Editing & $\begin{array}{l}\text { Students refine their texts for linguistic } \\
\text { accuracy, organization of ideas and } \\
\text { overall presentation. }\end{array}$ & $\begin{array}{l}\text { Teacher employs a } \\
\text { checklist to assist students } \\
\text { with the editing process. }\end{array}$ \\
\hline 6. Evaluating & Students seek final feedback. & $\begin{array}{l}\text { Teacher uses certain } \\
\text { evaluation criteria for } \\
\text { assessing students' overall } \\
\text { written performance. }\end{array}$ \\
\hline 7. Post-writing & $\begin{array}{l}\text { Students realize the significance of their } \\
\text { finished products and have a deep sense } \\
\text { of pride and ownership in their own } \\
\text { writing. }\end{array}$ & $\begin{array}{l}\text { Teacher shares students } \\
\text { finished written products } \\
\text { with an audience. }\end{array}$ \\
\hline
\end{tabular}

By preparing stages of learning experience, the teacher may give support to their students to be engaged in writing; starting from the teacher involving students in generating ideas, guiding the students in composing process, helping the students to go through revisions, evaluating the students overall written performance, until sharing the students ${ }^{\text {ee }}$ written products to an audience.

\section{Project-Based Learning}

As discussed above, to support the students' improvement and engagement, teacher needs not only to prepare stages of learning experience but also to apply appropriate teaching method.

One of the teaching methods for teaching writing is Project-based learning (PBL). PBL was initially promoted by John Dewey in 1897. The basis of PBL lies in the authenticity or real-life application. Students working as a team are given a "driven question" to respond to or answer, then directed to create an artefact to present their gained knowledge. Artefacts may include a variety of media such as writing, art, drawing, video, photography, or technology-based presentation.

Research has demonstrated that students in project-based learning classrooms get higher scores than students in traditional classroom (Krajcki and Blumenfeld, 2006, cited studies by Marx et al 2004, Rivet and Krajcki ,2004, and William and Linn, 2003). Furthermore, according to research conducted by The Autodesk Foundation, studies have shown that project-based learning is linked to significant improvements not only in student test scores but also in attendance and classroom engagement. Moreover, recent research by Shaffer (2018) as cited in Handhika et al (2018) demonstrated that there are several benefits of project based learning such as: PBL (1) encourages collaboration, (2) urges students to learn how to solve problems that are important to them, (3) fosters the student's creativity, (4) builds students' research skills, (5) encourages students to learn to take pride in their work, (6) helps students to learn to look at problems with critical 
thinking point of view, (7) supports students learn to manage obstacle more effectively, (8) assists students learn how to manage projects and assignments more efficiently, (9) helps students get to explore their curiosities, and (10) supports students take ownership over their projects.

The literature review of this research has focused on writing skill, writing process, and project-based learning. The project in this research is creating a magazine as one of the ways to publish students' writing assignment as the final stage of their "writing process". Next, the method of the research will be discussed.

\section{METHOD}

The magazine writing scheme described in this research is implemented in an "English II" class of students of the Bachelor of English Language Education degree program in one of universities in Bandung. English II class in this university is designed to focus on academic writing as well as academic presentation.

Especially for the academic writing, the class learning outcome is intended to make the students able to demonstrate their writing skills within collaborative settings, and to organize their ideas in complete sentences as well as to write complete paragraphs on the topic of interdisciplinary -may also include intercultural-teamwork.

Students build skills through discussing interdisciplinary topics, practicing writing a whole paragraph which include the elements of paragraph, such as: introductory sentences, topic sentence, supporting sentences, the closing and concluding sentences, working on magazine layout, flow of the paragraphs, and citation. Activities include group discussions, individual and group writing, and followed by creating and publishing a magazine. The class is designed using project-based learning method. Students in the English II program must complete English I class before matriculating in this class. Each course is a semester long of 16 weeks.

Twenty-six students were participating in the current research (10 females, 16 males) and had taken their two previous years of studies in the Bachelor of English Language Education program. Studentse ages ranged from 19 and 20 years old.

This study is qualitative research as it concerns with the process and products of the implementation of writing and publishing a magazine in a writing class in one of the universities in Bandung. Case study, according to Fraenkel and Wallen (2012), aims to understand a single case. The instrument of the research were observation to figure out how writing and publishing a magazine were designed and implemented and student interview to figure out the students ${ }^{\text {ee }}$ opinions toward publishing their writing assignment as the final stage of their writing process.

\section{FINDINGS AND DISCUSSION}

This part discusses the design and implementation and will be followed by the interview result.

\section{The Design and Implementation}

In this section, the design and implementation of the class activities in writing and publishing magazine are introduced to answer the first question that is how the scheme is designed and implemented. The scheme is presented in Figure 1, as follows: 


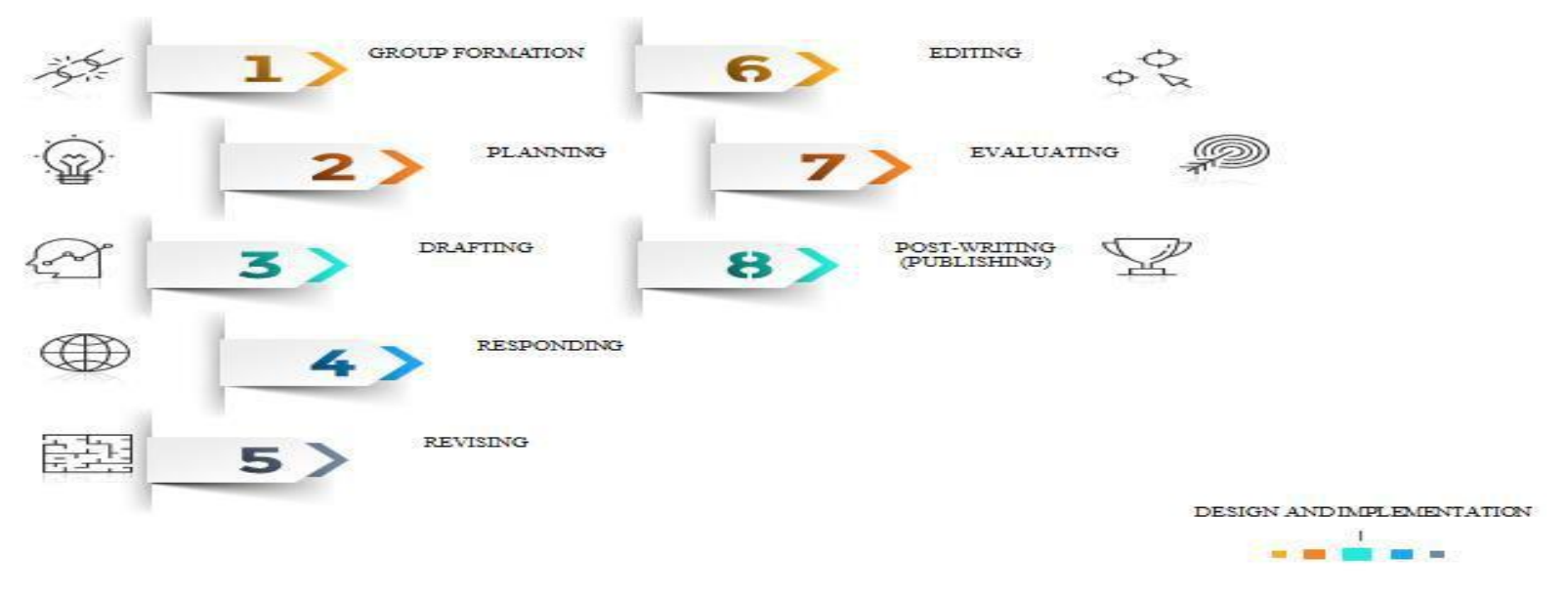

Figure 1. The Scheme of Writing and Publishing a Magazine

The scheme started from the group formation. The class consists of twenty-six students; they self-selected the members of the group by themselves. One group could only have maximum five members; this made 2 five-member and 4 four-member groups. The students self-selected the members of the group based on whether or not they can work together as a team. They reasoned that they needed to do the project of writing and publishing a magazine with members, who can communicate, collaborate, cooperate, and compromise well. The advantages of using self-selected rather than random assigned group have been pointed out in some researches. One of the researches was conducted by Chapman et al (2006) who have demonstrated that the students in the self-selected groups had better communication with each other, felt more enthusiastic about working together, took more interest in each other, and were more confident in other team members ${ }^{e e}$ abilities. They were also more likely than students in the randomly assigned groups to resolve conflict effectively and to be more comfortable asking others in their group for help. The students in the self-selected groups also indicated that it was less likely that group members would do others ee work. Furthermore, Chapman et al (2006) revealed that students in the self-selected groups had a positive overall attitude toward their group experience. The students in this class, too, felt that the group process was valuable, useful, and effective because they can communicate, collaborate, cooperate, and compromise well when working in the project.

After the students formed their self-selected groups then they experienced planning their writing. In this stage, the students were having collaborative discussion. Collaborative discussion is an activity in which students are sharing and building on ideas with others for a common goal. Studies (among others by Wu, Miller, NguyenJahiel, and Andersen, 2013) showed that collaborative discussions produced greater interest and engagement than conventional discussions. In this class, the students were having collaborative discussions that were sharing and building ideas with the members of the group for common goals: to decide what the contents and the purposes of their magazines were as well as who their target audience would be. Based on a target audience and the purpose of writing, the students then determined the register and tone of writing.

The students revealed that when having collaborative discussions, each student shared and built ideas and then made group decisions together. One of the results of their discussion is presented in Table 2. 
Table 2. The result of collaborative discussion on planning to write a magazine

\begin{tabular}{|c|c|c|c|}
\hline The Contents & The Purposes & $\begin{array}{c}\text { Target } \\
\text { Audience }\end{array}$ & The Tone and Register \\
\hline Creating a Tour and Travel Magazine. & $\begin{array}{l}\text { 1. To inform the } \\
\text { audience about }\end{array}$ & Travelers & Informal (Register) \\
\hline Title: Traveling to South Korea. & $\begin{array}{l}\text { where to go and } \\
\text { what to eat when }\end{array}$ & & $\begin{array}{l}\text { Light (Tone) } \\
\text { For example: So, if you }\end{array}$ \\
\hline $\begin{array}{l}\text { Table of Contents: } \\
\text { History of South Korea }\end{array}$ & in South Korea. & & $\begin{array}{l}\text { visit South Korea, you } \\
\text { should stop by Myeong- }\end{array}$ \\
\hline Tourism Destinations & To persuade the & & dong to taste the various \\
\hline Traditional Cuisine & audience to visit & & snacks offered there. \\
\hline The Culture & South Korea & & \\
\hline Korean Drama & & & \\
\hline
\end{tabular}

Next, the students started to draft their writing. This is called the drafting process. In this stage, the students were organizing their ideas and developing some form to their writing based on the guidance from the teacher. The student chose a narrow topic, for example South Korean Traditional Cuisine, and then she brainstormed to gather ideas and information for her draft, for example the type of the food based (rice, vegetable, meat) and the commonly used ingredients of South Korean traditional cuisine, next the student created an outline, and finally wrote the first draft. In brainstorming and gathering information to write their first draft, the students revealed that they read several sources to broaden their knowledge before writing. They read articles and journals from some websites, blogs, and printed material such as magazines. Reading, according to Maley (2009), helps improve writing. There is a well-established link between reading and writing. The fact that the more people read, the better they write is well-documented by Hafiz and Tudor (1989) as well as by Hoey (2005) as cited in Al Nafisah (2015).

After writing the first draft, then the students looked to the teacher and peers for support and feedback. This stage is known as responding. In this stage, the teacher and peers provided initial reactions to the students' first draft by checking for convention such as mechanics and spelling as well as relevance of ideas and sentences. After being given feedback both from peers and teacher, the students then wrote their second drafts.

In the stage of providing feedback by peers, the students mentioned that most of the time they were counting on one of the members of the group whom they believed have the highest mastery in L2 in terms of mechanics and spelling. Research suggests that providing feedback benefits not only for students who get comment on the writings but it benefits more to the ones who give comments and modify the texts (Tsui and $\mathrm{Ng}$, 2000, as cited by Sotoudehnama and Pilehvari, 2016). By being a critical reader of their classmates' writing, the students activate their linguistic competence and learn to examine, evaluate, and assess their own writing critically to identify the areas which need to be improved without being entirely dependent on their teacher's feedback (Rollinson, 2005). In this research, there is a fact that the students who provided feedback to their friends' writing got high grades in written test (earned scores more than 80 out of 100 points) and excellent grades in spoken test (earned scores more than 90 out of 100 points).

The next stage is the revising process. In this stage, the students capitalized on audience feedback to re-examine their drafts for clarity of intention and meaning and made necessary changes. The draft itself then developed into a complete idea in sentences, into a paragraph, and finally into a text. The text was expected to be constructed in a well-organized construction consisting introductory paragraph, the body of the paragraph with major and minor details, and concluding paragraph. The teacher 
took the students through the revision stage to help students shape and reshape their text into a final form.

According to Richards (2002), learning to write well is a difficult, lengthy process, one that induces anxiety and frustration in many learners. Writing a well-organized text or essay, according to the students in this research, is considered to be difficult. They mentioned that, this happens due to their lack of vocabulary and lack of writing practices. Most of the time, the students organized and developed their ideas in L1 and then had difficulty to translate their ideas in L2. To minimize this, Al-Gharabally (2015) suggests that the teacher should discourage translating into L2 from L1. Always ask students to try and think in English (L2) to improve their fluency and hence improve their writing.

The next stages are editing, evaluating, and finally publishing their texts. In the editing stage, the students refined their texts for linguistics accuracy, organization of ideas, and overall presentation. While in the evaluating stage, the students sought for final feedback. The teacher at these stages used certain evaluation criteria for assessing students' overall written performance. In this research the evaluation rubric for the students' magazine is presented in Table 3, as follows:

Table 3. Evaluation rubric for magazine

\begin{tabular}{|c|c|c|c|}
\hline No. & Components & Score (1-4) & Comment \\
\hline 1. & $\begin{array}{l}\text { Neatness of Project Result } \\
\text { (overall magazine is creative } \\
\text { and interesting; table of } \\
\text { contents; identities of } \\
\text { writers are clear) }\end{array}$ & & \\
\hline 2. & $\begin{array}{l}\text { Mechanics and Spelling } \\
\text { (good use of punctuations; } \\
\text { free from misspelling, } \\
\text { wrong capitalization, spaces } \\
\text { between words and lines) }\end{array}$ & & \\
\hline 3. & $\begin{array}{l}\text { Sentence Fluency \& } \\
\text { Construction of Idea (all } \\
\text { titles are in line with the } \\
\text { name of the magazine; the } \\
\text { order of information is } \\
\text { clear) }\end{array}$ & & \\
\hline 4. & $\begin{array}{l}\text { Lay-out \& Design } \\
\text { (matching colours; readable } \\
\text { fonts; good positions of } \\
\text { pictures and texts) }\end{array}$ & & \\
\hline 5. & $\begin{array}{l}\text { Overall Task Completion } \\
\text { (all elements of magazine } \\
\text { are present; proper } \\
\text { references) }\end{array}$ & & \\
\hline
\end{tabular}

There are five components to be evaluated by the teacher, namely: neatness of the project result, mechanics and spelling, sentence fluency and construction of ideas, layout and design, and overall task completion. The score is ranged from 1-4, in which 4 is great; this means the overall magazine is creative and interesting, table of contents and identities of writers are clear, good use of punctuations, free from misspelling, titles are in line with the name of the magazine, matching colours, good position of pictures and text, and all elements of magazine are present as well as proper references. Score 3 means good, while 2 is fair, and 1 is poor. The evaluation form is used as the feedback from the teacher. The students then revised the magazine before publishing it. 
The final stage of the students ${ }^{e c}$ writing process is publishing their writing assignment. The teacher and students shared the students ${ }^{\text {ee }}$ finished written products in the form of magazines with an audience. The magazines were published both in print and online. They were printed out and shared in campus community. They are also available online. Both the teacher and the students uploaded the magazines on their blogs and on social media; the links of the blogs were sent to other students and parents where the readers can leave comments. The comments are vary from mentioning that the magazines are pretty creative and have interesting articles to they have unmatched colour combinations and lack of relevant photographs or pictures.

\section{The Students' Opinion}

This part of the research paper figures out the students' opinions toward publishing their writing assignment as the final stage of their writing process.

All students in this research (100 per cent) have positive opinions of publishing their writing assignment. They mentioned that they have done their best on their work, and they need some way to get their writing recognized and read by others. They also believe that their ideas are interesting, useful, and meaningful to others. They, too, became more engaged and enthusiastic to revise their work to appeal to their audience.

\section{CONCLUSION}

Writing skill is a complicated skill because to construct writing, students need to constitute a variety of linguistic and non-linguistic components (Youn-Hee, 2011); however, there are several things that teachers can do to support the learning of the writing skills by preparing stages of learning experience and applying appropriate teaching method. By preparing stages of learning experience and applying appropriate teaching method, the teacher can help their students to have confidence that they, too, can be writing experts.

\section{REFERENCES}

Al-Gharabally. (2015). The Writing Difficulties Faced By L2 Learners and How to Minimize Them. Article in International Journal of English Language and Linguistics Research Vol.3,No.5, pp.42-49,August 2015. European Centre for Research Training and Development UK (www.eajournals.org) 42ISSN 20536305(Print), ISSN 2053-6313(online).

Al-Nafisah. (2015). The Effectiveness of an Extensive Reading Program in Developing Saudi EFL University Students" Reading Comprehension. Article in Arab World English Journal (AWEJ) Vol.6. No.2 June 2015.

Chapman, Toy, Meuter, Wright. (2006). Can't We Pick Our Own Groups? The Influence of Group Selection Method on Group Dynamics and Outcomes. Article in Journal of Management Education, 30 (4). January 2006.

Fraenkel and Wallen (2012). How to Design and Evaluate Research in Education. New York. McGraw-Hill Companies.

Handhika, Sunarno, Cari, Suparmi. (2018). The Influence of Project-based Learning on the Student Conception about Kinematics and Critical Thinking Skills. Article in Journal of Physics Conference Series 1013(1):012028. May 2018.

Hapsari, Sukavatee. (2018). Second language writing instruction: A recent practice in Indonesia. Retrieved from Research Gate. April 2018.

Krajcki and Blumenfeld. (2006). Project-Based Learning In: The Cambridge Handbook of the Learning Sciences. Cambridge. Cambridge University Press. 
Maley (2009). Extensive Reading: Why it is good for our students... and for us? Article in International Journal of English Language and Linguistics Research Vol.3, No.5, pp.42-49, August 2015. Published by European Centre for Research Training and Development UK (www.eajournals.org)

Richards. (2002). Methodology in Language Teaching. Cambridge. Cambridge University Press.

Schulten. (2018). Writing for an Audience Beyond the Teacher. The New York Times. The Language Network. November, 15, 2018.

Seow. (2014). How to respond to Student Writing Author(s). Teaching and Learning, 17(1), 78-85. Singapore. Institute of Education.

Sheedlo. (1998). Finding Reasons to Publish Student Writers. Article in Language Arts Journal of Michigan. Volume 14 Issue 2: Moving Towards Best Practice.

Sotoudehnama. (2016). The Impact of Peer Review on EFL Learners ${ }^{\text {ee }}$ Writing Proficiency: Global and Local Aspects. Retrieved from https://www.researchgate.net/publication

Wu, Miller, Nguyen-Jahiel, Andersen. (2013). Enhancing Motivation and Engagement through Collaborative Discussion. Article in Journal of Educational Psychology 105(3):622. August 2013.

Youn-Hee. (2011). Diagnosing EAP Writing Ability Using the Reduced Reparameterized Unified Model. Article in Sage Journal https://doi.org 